Vol. 1, No. 4, 2019

\title{
RANCANG BANGUN SISTEM INFORMASI MANAJEMEN GUDANG APOTEK MENGGUNAKAN MODEL SOFTWARE DEVELOPMEN LIFE CYCLE (SDLC) DI APOTEK MARIFA
}

\author{
Abdul Muiz Hasyim ${ }^{1}$, Yoyok Seby Dwanoko², Abdul Aziz ${ }^{3}$ \\ Sistem Informasi, Universitas Kanjuruhan Malang ${ }^{1,2}$ \\ Teknik Informatika, Universitas Kanjuruhan Malang ${ }^{3}$ \\ abdulmuizhasyim@gmail.com ${ }^{1}$, yoyokseby@unikama.ac.id ${ }^{2}$, abdulaziz@unikama.ac.id ${ }^{3}$
}

\begin{abstract}
Abstrak. Sistem informasi manajemen gudang apotek ini dibangun untuk membantu mengelola stok obat yang ada di gudang apotek. Fokus penelitian pengembangan ini mengacu pada pendekatan menggunakan model SDLC. Jenis data yang digunakan pada penelitian ini adalah jenis kualitatif, yaitu prosedur penelitian yang menghasilkan data tidak dalam bentuk angka. Instrumen penelitian dilakukan dengan observasi dan wawancara. Dalam penelitian Deni Eko Purwanto pada tahun 2013 sistem informasi pink apotek pacitan dibangun menggunakan model waterfall. Sedangkan pada penelitian ini dilakukan menggunakan model SDLC dan uji UAT. Hasil yang disimpulkan dari penelitian ini adalah dengan adanya sistem informasi manajemen gudang apotek, berdasarkan uji user acceptance test menunjukkan $86.43 \%$ responden menyatakan setuju bahwa dengan adanya sistem informasi manajemen gudang dapat membantu apotek MARIFA dalam mengelola data obat.
\end{abstract}

Kata Kunci: Rancang Bangun, Manajemen Gudang, SDLC, Apotek

\section{PENDAHULUAN}

Perkembangan teknologi saat ini semakin pesat, banyak sekali teknologi-teknologi canggih yang telah diciptakan dan bertujuan untuk mempermudah manusia dalam melakukan aktifitas dan pekerjaannya. Salah satunya dalam pengelolaan data obat-obatan pada toko obat (apotek), yang antara lain mengelola data obat-obatan yang ada termasuk stok obat.

Apotek adalah sarana pelayanan kefarmasian tempat dilakukan praktek kefarmasian oleh Apoteker. Apotek Marifa sendiri merupakan salah satu tempat yang memberikan sarana pelayanan kefarmasian dan juga praktek kefarmasian [1].

Apotek MARIFA merupakan salah satu apotek yang mengatur manajemen gudang secara konvensional dengan mencatat transaksi tersebut kedalam sebuah buku defekta dan belum memanfaatkan teknologi komputer. Adapun transaksi yang dilakukan secara konvensional diantaranya pendataan stok obat, pembelian obat dari supplier, cek obat kadaluarsa dan laporan kepada pemilik. (Sumber : Hasil Observasi dan Wawancara dengan PSA dan TTK Apotek MARIFA) Sehingga pegawai dan pemilik apotek mengalami kesulitan dalam mengolah data stok obat karena begitu banyak stok obat yang ada pada apotek. Pegawai kesulitan dalam mencari data obat dan pegawai juga pemilik juga kesulitan dalam mengetahui tanggal kadaluarsa obat - obatan yang ada pada apotek. Dimana seharusnya obat yang sudah mendekati tanggal kadaluarsa harus dikembalikan kepada supplier atau distributor sebelum tanggal kadaluarsa. Untuk mengetahui tanggal kadaluarsa, pegawai hanya melihat langsung pada kemasan obat yang kadaluarsa. Dengan adanya masalah diatas, sehingga pegawai kesulitan dalam memberikan laporan kepada pemilik karena kurangnya pengelolaan data obat yang baik.

Sistem Informasi Manajemen Gudang Apotek ini dibangun dengan tahapan SDLC dari tahap analisis kebutuhan sistem hingga tahapan testing yang digunakan untuk mengetahui stok obat dan segala transaksi pada gudang apotek. Dengan adanya sitem informasi manajemen gudang apotek ini dapat memberikan informasi mengenai stok obat dan juga dapat mengelola data obat, penerimaan obat, permintaan obat, obat keluar dan mendeteksi obat kadaluarsa serta memberikan laporan kepada pemilik dalam bentuk rekap setiap transaksi obat. 
Keterbatasan dari penelitian rancang bangun sistem informasi ini dibangun menggunakan model SDLC dari tahap analisis sistem hingga tahap pengujian sistem. Keterbatasan dari penelitian rancang bangun sistem informasi ini dibangun menggunakan model SDLC dari tahap analisis sistem hingga tahap pengujian sistem.

Adapun jurnal rujukan sebagaai refrensi yang telah berhasil yaitu "Implementasi Software Development Life Cycle (SDLC) Dalam Penerapan Pembangunan Aplikasi Perangkat Lunak" yang ditulis oleh Yoyok Seby Dwanoko pada tahun 2016 dengan kesimpulan bahwa penerapan software development life cycle (SDLC) dapat mengurangi terjadinya software crisis karena dalam tahapannya sangat detail mulai dari tahapan analisa sampai dengan maintenance jika diimplementasikan akan menghasilkan dua produk yaitu dokumen spesifikasi kebutukan perangkat lunak (SKPL) dan sebuah aplikasi sistem informasi yang sesuai dengan kebutuhan [2].

Jurnal rujukan "Pembangunan Sistem Informasi Apotek Pink Pacitan" yang ditulis oleh Deni Eko Purwanto pada tahun 2013 dengan kesimpulan sebagai berikut: 1) Dengan adanya Sistem Informasi Apotek Pink ini, dapat membantu pihak Apotek dalam mengatasi permasalahan yang ada yaitu proses pendataan yang masih menggunakan pembukuan. 2) Sistem Informasi Apotek Pink ini dapat digunakan untuk melakukan penyimpanan dan pengolahan data- data pada Apotek, diantaranya pengolahan data pengguna, dataobat, data penjualan serta mempermudah dalam pembuatan laporan kepada pimpinan, baik laporan data obat maupun laporan data penjualan. 3) Dapat mengetahui obat yang mendekati kedaluarsa [3].

Jurnal rujukan "Rancang Bangun Aplikasi Pengelolaan Pada Apotek Sinar Jaya" yang ditulis oleh Michael Richie Panjaya, dkk pada tahun 2016 dengan kesimpulan sebagai berikut: 1)Aplikasi telah menghasilkan informasi mengenai Sistem Administrasi pada bagian Penjualan berupa warning pada pemilihan obat apabila obat tersebut tersisa minimum stok dan bagian gudang dapat menentukan minimum stok pada tiap - tiap obat dan informasi yang dihasilkan yaitu laporan detail mengenai laporan pada penjualan obat, informasi barang yang laku di jual, dan pemantauan terhadap barang yang kadaluarsa. 2) Dengan adanya aplikasi Pengelolaan, maka Apotek Sinar Jaya dapat menggunakan informasi tersebut sebagai salah satu dasar dalam Administrasi penjualan pada Apotek [4].

\section{METODE PENELITIAN}

\section{A. Model Penelitian Pengembangan}

Metode penelitian yang digunakan dalam penelitian ini bersifat prosedural dan deskriptif. Pengembangan sistem informasi manajemen apotek pada Apotek MARIFA di Desa Kanigoro Kabupaten Kediri, peneliti mengacu pada model pengembangan SDLC. SDLC merupakan tahapan - tahapan pekerjaan yang dilakukan oleh analisis sistem dan programmer dalam membangun sebuah sistem informasi [2]. Model SDLC ini dipilih karena menggunakan pendekatan yang sistematis dalam tahap pengembangannya dari tahap analisis kebutuhan sistem hingga tahap perawatan sistem. Dalam penelitian ini tahap yang dilakukan yaitu dari tahap analisis kebutuhan sistem hingga tahap testing. Adapun tahapan pada SDLC dapat dilihat pada Gambar 1.

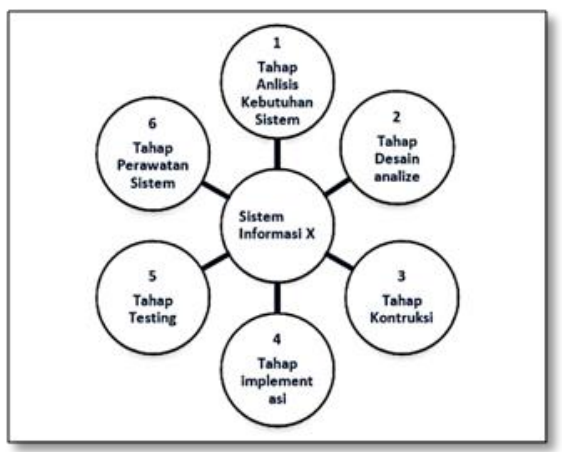

Gambar 1 Langkah Pengembangan SDLC

1. Analisis Kebutuhan Sistem 
Dalam tahap analisis ini dilakukan observasi dan wawancara yang dilakukan kepada PSA dan TTK Apotek MARIFA, serta melakukan penyusunan kebutuhan hardware dan software.

2. Desain Analize

Pada tahapan ini dilakukan 3 kegiatan yaitu, membuat tabel fungsional, merancang desain sistem, dan membuat desain GUI.

3. Kostruksi

Tahapan pemrograman mengimlementasikan hasil rancangan ke dalam baris kode dan tampilan sistem yang berjalan sesuai dengan fungsinya.

4. Implementasi tabel user.

Tahapan ini menghasilkan sistem informasi manajemen gudang apotek dan

5. Testing

6. Perawatan Sistem

Pada tahap ini dilakukan uji blackbox dan uji user acceptance. sistem.

Tahapan ini merupakan tahapan yang digunakan dalam melakukan evaluasi

\section{B. Instrumen Pengumpulan Data}

Instrumen pengumpulan data dilakukan dengan wawancara tersetruktur. Wawancara terstruktur merupakan wawancara menggunakan pedoman wawancara yang telah disusun untuk pengumpulan datanya. Wawancara diajukan kepada apoteker di Apotek Marifa, Desa Kanigoro Kabupaten Kediri.

\section{Teknik Analisis Data}

Teknik analisis data yang digunakan dalam penelitian ini menggunakan tahapan SDLC. Proses analisis data dengan menggunakan tahapan SDLC sebagai berikut :

1. Melakukan analisa sistem untuk memperoleh pengertian dari permasalahan permasalahan, efisiensi, dan pertimbangan-pertimbangan yang mengarah ke Rancang Bangun Sistem Informasi, serta mencari kendala yang dihadapi dalam sistem sehingga dapat menentukan solusi.

2. Observasi untuk pengumpulan data dan informasi.

3. Wawancara sebagai dasar untuk mengetahui kebutuhan aktor yang terlibat dalam sistem, kebutuhan fungional mulai dari input, proses dan output pada sistem yang dibutuhkan.

4. Dari wawancara dan observasi yang telah dilakukan maka ditemukannya identifikasi masalah yang akan digunakan untuk pembangunan sistem informasi.

\section{HASIL DAN PEMBAHASAN}

\section{A. Analisis Kebutuhan Sistem}

Dalam tahap ini dilakukan observasi dan wawancara dengan mengajukan pertanyaan mengenai kebutuhan dan manajemen apotek saat ini kepada PSA dan TTK Apotek MARIFA.Setelah dilakukan observasi dan wawancara, dalam tahap ini juga menghasilkan tabel kebutuhan hardware dan software yang menyesuaikan dengan kebutuhan apotek.

B. Desain (Design Analyze)

Pada tahap desain ini merupakan lanjutan dari tahap analisis kebutuhan sistem. Dalam tahap desain ini dilakukan 3 tahap yang terdiri dari :

1. Membuat tabel fungsional dengan tujuan menyediakan menu dan submenu pada aplikasi yang dibangun ini. Tabel fungsional dapat dilihat pada Tabel 1.

Tabel 1 Tabel Fungsional

\begin{tabular}{ll}
\hline No. & Deskripsi \\
1. & Mengolah Data User \\
2. & Mengolah Data Obat \\
3. & Mengolah Data Supplier \\
4. & Mendeteksi Obat Kadaluarsa \\
5. & Melihat Laporan Data Obat \\
\hline
\end{tabular}


2. Membuat Tabel Aktor dan merancang desain sistem menggunakan UML. UML memiliki jenis - jenis diagram [5] yang dibagi menjadi Use Case Diagram, Sub Use Case Diagram, Activity Diagram, Sequence Diagram dan Class Diagram yang bertujuan untuk mempermudah proses pembuatan sistem.

Tabel aktor digunakan untuk memberikan hak akses kepada setiap aktor dengan perannya masing - masing. Adapun tabel aktor dapat dilihat pada Tabel 2.

Tabel 2 Aktor

\begin{tabular}{|c|c|c|c|}
\hline No. & Aktor & Peran & Hak Akses \\
\hline 1. & Administrator & $\begin{array}{l}\text { Berperan sebagai user yang memanipulasi } \\
\text { seluruh data. }\end{array}$ & $\begin{array}{l}\text { 1. Mastering } \\
\text { 2. Transaksi }\end{array}$ \\
\hline 2. & $\begin{array}{l}\text { Operator } \\
\text { Gudang }\end{array}$ & $\begin{array}{l}\text { Berperan sebagai user yang melakukan } \\
\text { beberaoa kegiatan transaksi }\end{array}$ & $\begin{array}{ll}\text { 1. Transaksi Obat } \\
\text { Keluar } \\
\text { 2. Transaksi } \\
\text { Penerimaan Obat }\end{array}$ \\
\hline 3. & $\begin{array}{l}\text { Pemilik } \\
\text { Apotek }\end{array}$ & Berperan sebagai user yang menerima report. & Laporan \\
\hline 4. & $\begin{array}{l}\text { Operator } \\
\text { Apotek }\end{array}$ & User yang melakukan permintaan dari apotek. & Permintaan Obat \\
\hline
\end{tabular}

Use case diagram utama merupakan use case yang menggambarkan dari sub use case yang ada dalam tahapan desain ini. Adapun use case utama dapat dilihat pada Gambar 2.

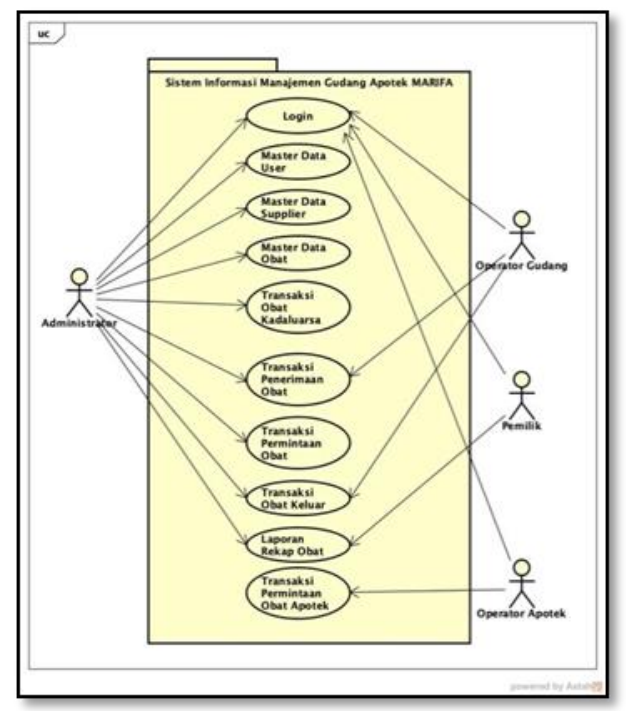

Gambar 2 Use Case Diagram Utama

Di dalam use case utama terdapat sub use case yang dapat menjelaskan aksi dari aktor. Sub use case yang ada pada penelitian ini adalah :

1. Login digunakan untuk memvalidasi pengguna agar dapat menggunakan fitur yang sesuai dengan hak akses pengguna.

2. Master Data User digunakan oleh administrator untuk mgelola data user serta memberikan hak akses kepada user.

3. Master Data Supplier digunakan oleh administrator untuk mengelola data supplier.

4. Master Data Obat digunakan oleh administrator untuk mengelola data obat.

5. Transaksi Obat Kadaluarsa digunakan oleh administrator untuk mengelola data obat yang kadaluarsa.

6. Transaksi Permintaan Obat digunakan oleh administrator untuk mendeteksi obat yang habis dan untuk mengelola data permintaan obat.

7. Penerimaan Obat digunakan oleh administrator dan operator untuk mengelola 
data obat yang diterima atau data obat masuk.

8. Obat Keluar digunakan oleh administrator dan operator untuk mengelola data obat yang keluar dari gudang.

9. Laporan digunakan oleh administrator dan pemilik untuk mlihat laporan dalam bentuk rekap setiap jenis transaksi obat.

10. Transaksi Permintaan Obat Apotek digunakan oleh operator apotek untuk melakukan permintaan obat dari apotek

Adapun salah satu sub use case dalam penelitian ini dapat dilihat pada Gambar 3.

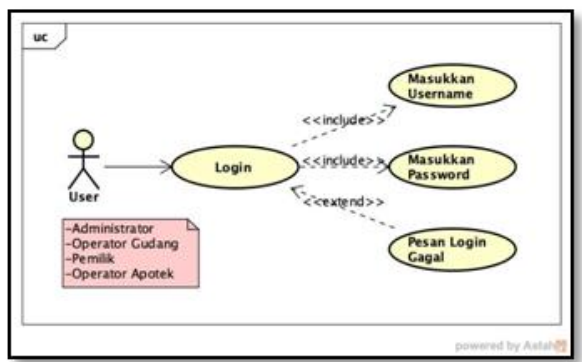

Gambar 3 Sub Use Case Diagram Login

Setelah sub use case diperlukan adanya activity diagram yang digunakan untuk menjelaskan aktivitas yang dilakukan baik dari aktor dan sistem. Adapun salah satu activity diagram dalam penelitian ini dapat dilihat pada Gambar 4.

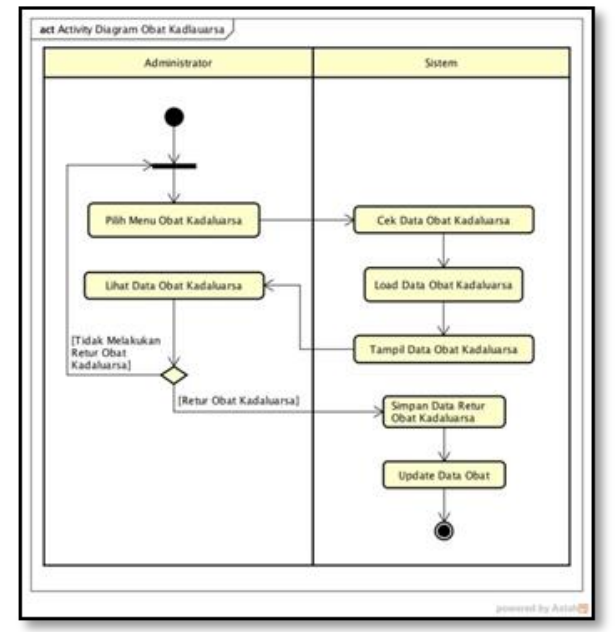

\section{Gambar 4 Activity Diagram Transaksi Obat Kadaluarsa}

Dalam activity diagram transaksi obat kadaluarsa terdapat dua partisi yaitu administrator dan sistem yang dimana administrator melakukan aksi pilih menu obat kadaluarsa, sistem melakukan cek data obat kadaluarsa, load data obat kadaluarsa dan menampilkan data obat kadaluarsa. Terdapat kondisi apabila administrator melakukan retur obat kadaluarsa maka sistem akan menyimpan data retur obat kadaluarsa dan melakukan update data obat. Sedangkan jika administrator tidak melakukan retur obat kadaluarsa maka sistem tidak terjadi aksi pada sistem.

Activity diagram yang telah dibuat memerlukan adanya sequence diagram yang digunakan untuk menjelaskan proses yang terjadi pada sistem. Adapun salah satu sequence diagram dalam penelitian ini dapat dilihat pada Gambar 5. 


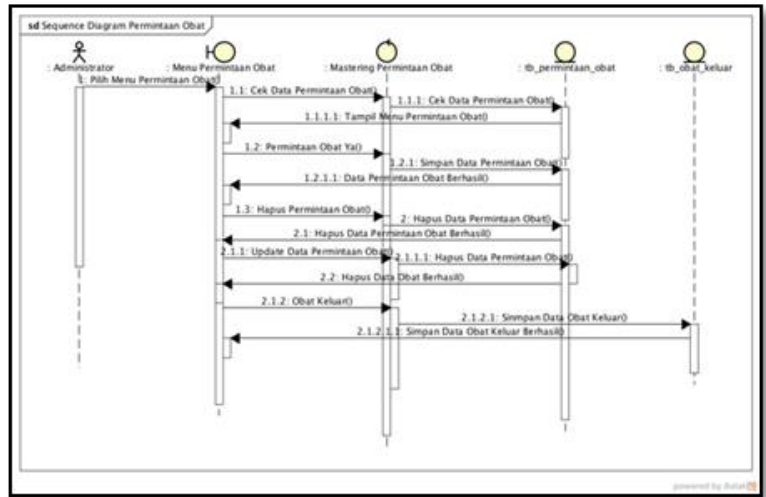

Gambar 5 Sequence Diagram Transaksi Permintaan Obat

Pada sequence diagram transaksi permintaan obat terdapat administrator sebagai aktor, boundary yaitu menu permintaan obat dan dua entity yaitu tb_permintaan_obat dan tb_obat_keluar.

Classs diagram pada penelitian ini memiliki 13 class yaitu, (1)Obat (2)User (3)Jabatan (4)Supplier (5)Obat Kadaluarsa (6)Detail Obat Kadaluarsa (7)Permintaan Obat (8)Detail Permintaan Obat (9)Penerimaan Obat (10)Detail Penerimaan Obat (11)obat Keluar (12)Satuan (13)Jenis Obat. Adapun class diagram dalam penelitian ini dapat dilihat pada Gambar 6.

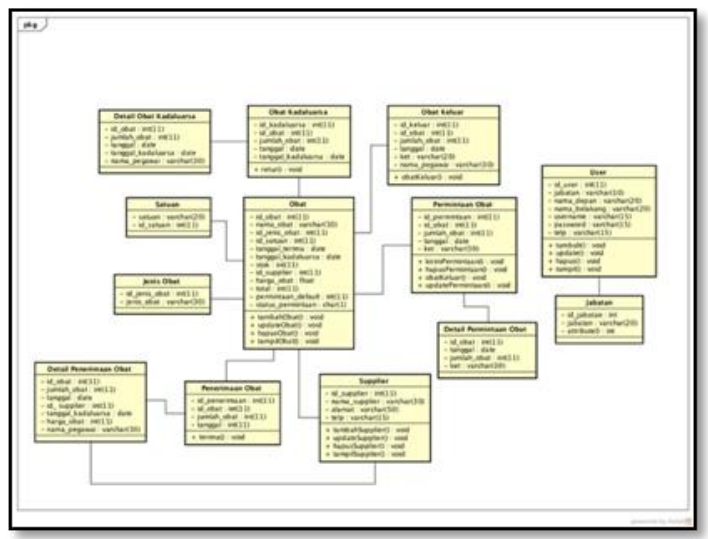

Gambar 6 Class Diagram

3. Membuat desain GUI dari setiap halaman pengguna.

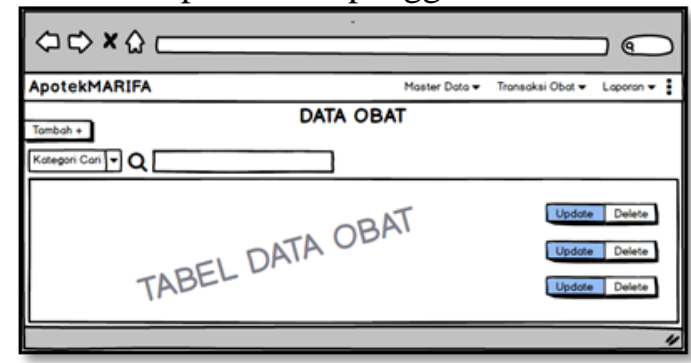

Gambar 7 Desain GUI Master Data Obat

\section{Kostruksi (Design and Coding Program)}

Pada tahap proses konstruksi program dilakukan pembuatan kode program sesuai hasil tahapan desain produk. Tahapan pemrograman mengimlementasikan hasil rancangan ke dalam baris kode dan tampilan sistem yang berjalan sesuai dengan fungsinya. 


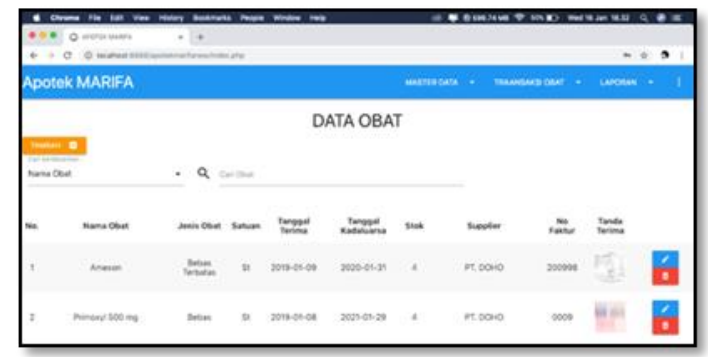

Gambar 8 User Interface Sistem Informasi Manajemen Gudang Apotek

\section{Implementasi}

Pada tahap ini sistem informasi manajemen gudang apotek menghasilkan data, menjalankan proses transaksi dan menampilkan laporan yang dibutuhkan apotek yang sudah dibuat pada tahap konstruksi program. Pada tahap ini juga dilakukan pemilihan user yang terlibat langsung dengan sistem. Adapun pemilihan user yang terlibat langsung dengan sistem dapat dilihat langsung pada Tabel 3.

Tabel 3 User

\begin{tabular}{lll}
\hline \multicolumn{1}{c}{ Hak Akses } & \multicolumn{1}{c}{ Nama } & Jabatan \\
Administrator & Maha Eko & PSA \\
Pemilik & Eko Mahmudi & Pemilik \\
Pegawai & Bintan Sri Rahayu & TTK Apotek \\
\hline
\end{tabular}

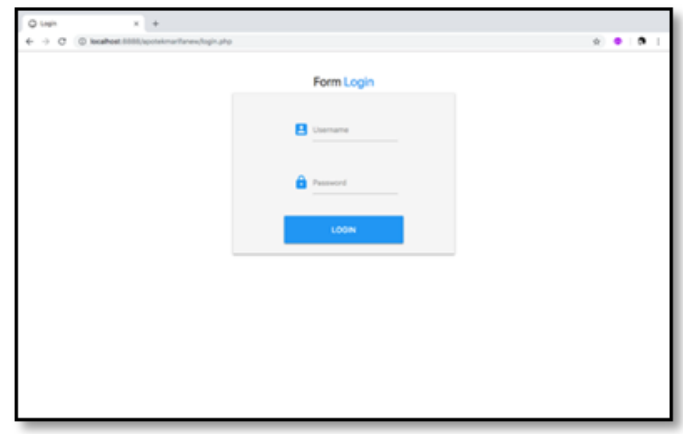

Gambar 9 Login

Gambar 9 merupakan halaman login yang digunakan untuk melakukan validasi pengguna sesua dengan hak akses yang diberikan.

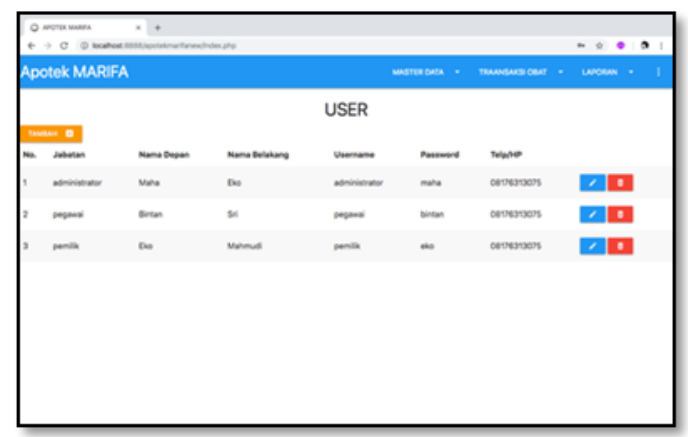

Gambar 10 Master User

Gambar 10 merupakan halaman master user yang dapat di akses oleh administrator. Pada halaman ini administrator dapat melakukan tambah, hapus dan update data user. 


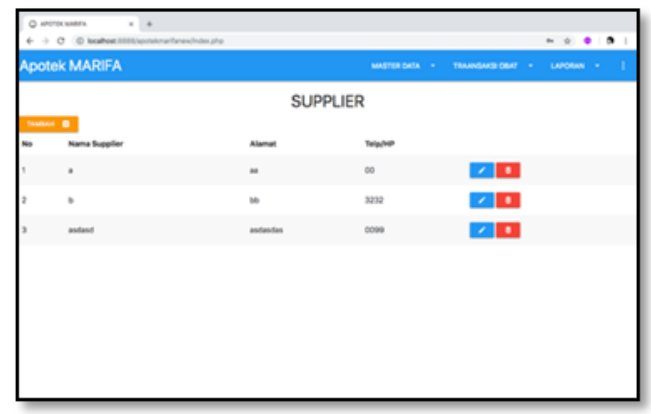

Gambar 11 Master Supplier

Gambar 11 merupakan halaman master supplier yang dapat di akses oleh administrator. Pada halaman ini administrator dapat melakukan tambah, hapus dan update data supplier.

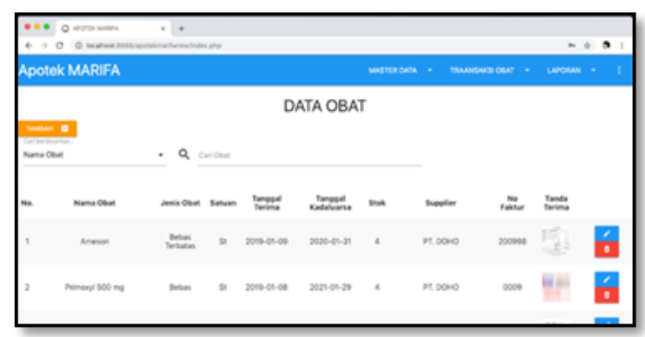

Gambar 12 Master Obat

Gambar 12 merupakan halaman master obat yang dapat di akses oleh administrator. Pada halaman ini administrator dapat melakukan tambah, hapus dan update data obat.

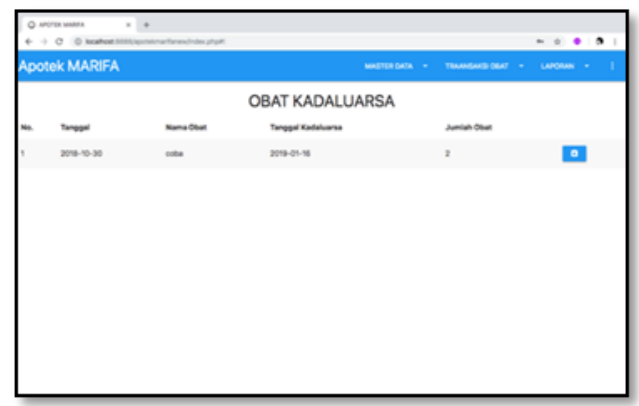

Gambar 13 Transaksi Obat Kadaluarsa

Gambar 13 merupakan halaman transaksi obat kadaluarsa yang dapat di akses oleh administrator. Pada halaman ini administrator dapat melihat data obat kadaluarsa dan melakukan retur obat kadaLuarsa.

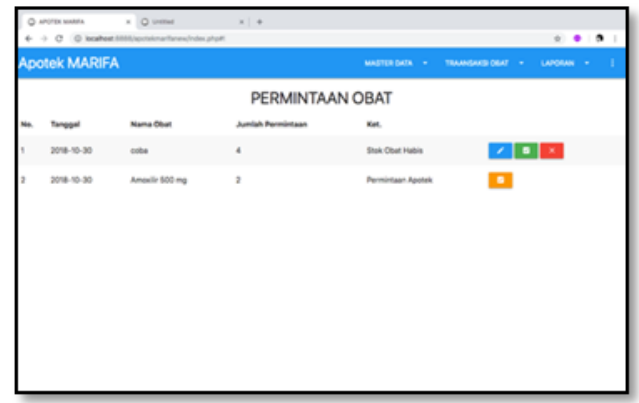

Gambar 14 Transaksi Permintaan Obat 
Gambar 14 merupakan halaman transaksi permintaan obat yang dapat di akses oleh administrator. Pada halaman ini administrator dapat melihat data permintaan obat dan mengirim data permintaan obat.

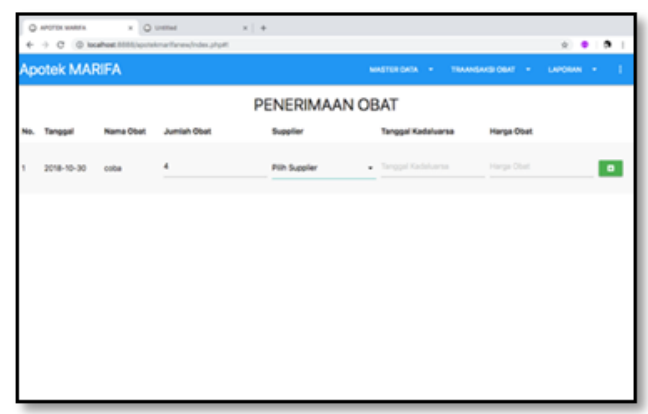

Gambar 15 Transaksi Penerimaan Obat

Gambar 15 merupakan halaman transaksi penerimaan obat yang dapat di akses oleh administrator. Pada halaman ini administrator dapat melakukan update dan penerimaan data obat.

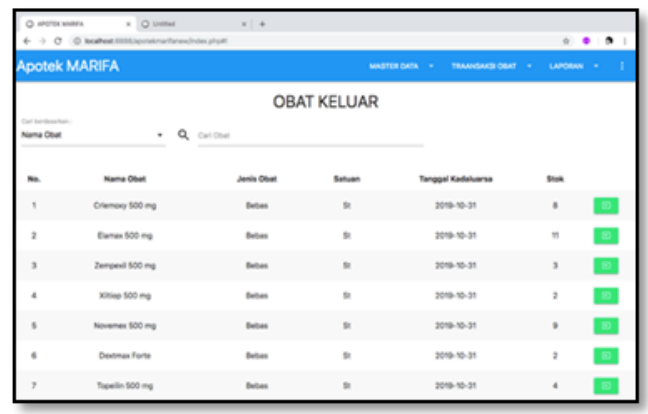

Gambar 16 Transaksi Obat Keluar

Gambar 16 merupakan halaman transaksi obat keluar yang dapat di akses oleh administrator dan operator gudang. Pada halaman ini user dapat melakukan aksi obat keluar dan cari data obat.

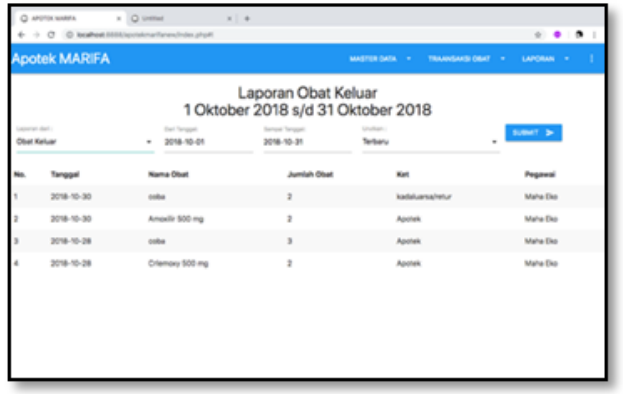

Gambar 17 Laporan

Gambar 17 merupakan halaman laporan yang dapat di akses oleh administrator dan pemilik. Pada halaman ini user dapat melihat laporan berdasarkan kategori dan tanggal yang ditentukan.

\section{E. Pengujian Sistem (Testing)}

Setelah konsturuksi program selesai kemudian dilakukan pengujian produk dengan blackbox testing dan user acceptance test. Pengujian dilakukan dengan membuktikan bahwa semua objek dalam sistem dapat berjalan sesuai fungsi yang diberikan [6]. Pengujian ini dilakukan dengan menguji semua fungsi di setiap halaman dilanjutkan dengan uji user acceptance test. Hasil dari pengujian sistem blackbox testing dapat dilihat pada Tabel 4 . 
Tabel 4 Uji Black Box

\begin{tabular}{|c|c|c|c|c|}
\hline No. & Fungsi & Pengujian & Hasil yang Diharapkan & Keterangan \\
\hline 1. & Login & $\begin{array}{l}\text { Masukkan username dan } \\
\text { password sesuai dengan } \\
\text { data user. }\end{array}$ & $\begin{array}{l}\text { Masuk ke halaman } \\
\text { dashboard pengguna. }\end{array}$ & Berhasil \\
\hline 2. & Master Obat & $\begin{array}{l}\text { Melihat detail data obat } \\
\text { dan memanipulasi data } \\
\text { obat }\end{array}$ & $\begin{array}{l}\text { Menampilkan data obat, } \\
\text { detail obat dan } \\
\text { menyimpan perubahan } \\
\text { data. }\end{array}$ & Berhasil \\
\hline 3. & Master User & $\begin{array}{l}\text { Melihat detail data user } \\
\text { dan memanipulasi data } \\
\text { user. }\end{array}$ & $\begin{array}{l}\text { Menampilkan data user } \\
\text { dan menyimpan } \\
\text { perubahan data user. }\end{array}$ & Berhasil \\
\hline 4. & Master & $\begin{array}{l}\text { Melihat detail data } \\
\text { supplier dan memanipulasi } \\
\text { data supplier }\end{array}$ & $\begin{array}{l}\text { Menampilkan data } \\
\text { supplier dan menyimpan } \\
\text { data supplier. }\end{array}$ & Berhasil \\
\hline 5. & $\begin{array}{l}\text { Transaksi Obat } \\
\text { Kadaluarsa }\end{array}$ & $\begin{array}{l}\text { Melihat data obat } \\
\text { kadaluarsa dan melakukan } \\
\text { retur obat kadaluarsa } \\
\text { dengan menekan tombol } \\
\text { retur. }\end{array}$ & $\begin{array}{l}\text { Menampilkan data obat } \\
\text { kadaluarsa apabila ada. } \\
\text { Merubah data stok obat } \\
\text { dan meyimpan data obat } \\
\text { kadaluarsa. }\end{array}$ & Berhasil \\
\hline 6. & $\begin{array}{l}\text { Transaksi } \\
\text { Permintaan Obat }\end{array}$ & $\begin{array}{l}\text { Melihat data permintaan } \\
\text { obat dan melakukan } \\
\text { proses transaksi } \\
\text { permintaan obat dengan } \\
\text { menekan button update } \\
\text { permintaan, hapus } \\
\text { permintaan, lakukan } \\
\text { permintaan dan kirim } \\
\text { permintaan obat dari } \\
\text { apotek. }\end{array}$ & $\begin{array}{l}\text { Menampilkan data } \\
\text { permintaan obat apabila } \\
\text { ada permintaan dari stok } \\
\text { kosong dana tau } \\
\text { permintaan dari apotek. } \\
\text { Mengirim data } \\
\text { permintaan obat kepada } \\
\text { penerimaan obat. } \\
\text { Menghapus data } \\
\text { permintaan obat. } \\
\text { Merubah jumlah } \\
\text { permintaan obat. } \\
\text { Merubah data obat } \\
\text { apabila permintaan dari } \\
\text { apotek. }\end{array}$ & Berhasil \\
\hline 7. & $\begin{array}{l}\text { Transaksi } \\
\text { Penerimaan Obat }\end{array}$ & $\begin{array}{l}\text { Melihat data penerimaan } \\
\text { obat dan memasukkan } \\
\text { data obat diterima. } \\
\text { Melakukan proses } \\
\text { transaksi dengan menekan } \\
\text { button terima obat. }\end{array}$ & $\begin{array}{l}\text { Menampilkan data } \\
\text { penerimaan obat } \\
\text { menyimpan perubahan } \\
\text { data penerimaan obat dan } \\
\text { data obat. }\end{array}$ & Berhasil \\
\hline 8. & Transaksi & $\begin{array}{l}\text { Melihat data obat, } \\
\text { memilih obat dan } \\
\text { masukkan jumlah obat } \\
\text { keluar setelah menekan } \\
\text { button obat keluar. }\end{array}$ & $\begin{array}{l}\text { Menampilkan data obat, } \\
\text { menyimpan perubahan } \\
\text { data obat. }\end{array}$ & Berhasil \\
\hline 9. & Laporan & $\begin{array}{l}\text { Melihat laporan } \\
\text { berdasarkan kategori } \\
\text { laporan dan tanggal. }\end{array}$ & $\begin{array}{l}\text { Menampilkan data } \\
\text { laporan. }\end{array}$ & Berhasil \\
\hline
\end{tabular}

Uji User Acceptance test dalam penelitian ini dilakukan dengan memberikan kuesioner kepada 3 responden yaitu PSA Apotek, Supervisor Apotek dan TTK Apotek. Berdasarkan hasil Analisa, didapatkan rata-rata untuk Aspek Sistem diketahui sebesar 81.3\%, menyatakan setuju bahwa sistem informasi manajemen gudang apotek ini secara pengembangan sudah memiliki tampilan yang baik, user interface yang mudah diterima, mudah dioperasikan dan telah sesuai 
dengan kebutuhan.Pada Aspek Pengguna diketahui rata-rata sebesar 88.4\%, hal ini dapat disampaikan bahwa bagi pengguna aplikasi ini mudah untuk membantu pengguna dalam mengolah data. Sedangkan untuk aspek interaksi diketahui sebesar $89.6 \%$,menyatakan setuju bahwa sistem informasi manajemen gudang apotek ini mudah digunakan, semua fungsi berjalan normal dan meningkatkan kinerja.

\section{PENUTUP}

Setelah melakukan tahap SDLC, dihasilkan sistem informasi manajemen gudang di apotek MARIFA, Desa Kanigoro, Kabupaten Kediri. Setelah dilakukan uji coba menggunakan user acceptance test, diperoleh data yang menyatakan bahwa responden mendukung pengembangan sistem informasi manajemen gudang apotek sebesar $86.43 \%$. Sehingga dapat ditarik kesimpulan bahwa sistem yang dibuat dapat membantu apotek dalam mengelola stok obat pada apotek MARIFA.

\section{DAFTAR PUSTAKA}

[1] R. Indonesia, "Peraturan Menteri Kesehatan No. 9 Tahun 2017 tentang Apotek," Menteri Kesehatan Republik Indonesia, Jakarta, 2017.

[2] Y. S. Dwanoko, "Implementasi Software Development Life Cycle (SDLC) Dalam Penerapan Pembangunan Aplikasi Perangkat Lunak," Jurnal Teknologi Informasi, vol. 7, no. 2, pp. 84-93, 2016.

[3] D. E. Purwanto, "Pembangunan Sistem Informasi Apotek Pink Pacitan," Journal Speed - Sentra Penelitian Engineering dan Edukasi, vol. 5, no. 3, pp. 69-72, 2013.

[4] M. A. \&. M. S. E. Michael Richie Panjaya, "Rancang Bangun Aplikasi Pengelolaan Pada Apotek Sinar Jaya," JSIKA, vol. 5, no. 9, pp. 1-7, 2016.

[5] M. M. \&. Oktafianto, Analisis dan Perancangan Sistem Informasi Menggunakan Model Terstruktur dan UML, Yogyakarta: ANDI, 2016.

[6] R. F. F. \&. H. R. M. Sidi Mustaqbal, "Pengujian Aplikasi Menggunakan Black Box Testing Boundary Value Analysis (Studi Kasus : Aplikasi Prediksi Kelulusan SNMPTN)," Jurnal Ilmiah Teknologi Informasi Terapan (JITTER), vol. 1, no. 3, pp. 3136, 2015. 